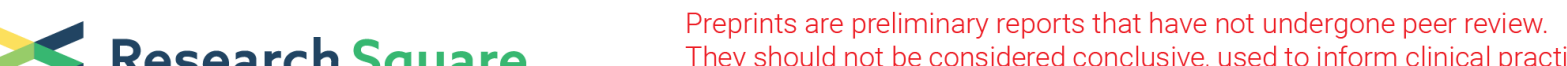 $\begin{array}{ll}\text { Research Square } & \text { They should not be considered conclusive, used to inform clinical practice, } \\ \text { or referenced by the media as validated information. }\end{array}$
}

\section{Mining database for the clinical significance and prognostic value of ESRP1 in skin cutaneous melanoma}

\section{Baihe Wang}

Chinese Academy of Medical Sciences \& Peking Union Medical College Hospital of Skin Diseases and Institute of Dermatology

\section{Caixia Kou}

Chinese Academy of Medical Sciences \& Peking Union Medical College Hospital of Skin Diseases and Institute of Dermatology

Jianfang Sun ( $\square$ pysdermatology@163.com )

Xiulian Xu

Chinese Academy of Medical Sciences \& Peking Union Medical College Hospital of Skin Diseases and Institute of Dermatology

\section{Primary research}

Keywords: ESRP1, Prognosis, Melanoma, Immune infiltration

Posted Date: February 25th, 2020

DOI: https://doi.org/10.21203/rs.2.24481/v1

License: (c) (1) This work is licensed under a Creative Commons Attribution 4.0 International License. Read Full License 


\section{Abstract}

The authors have removed this preprint from Research Square. 